\title{
Identification of Coral Reef Conditions Using Hydro-Acoustic Technology in Giligenting Island, Sumenep Regency Indonesia
}

\author{
Fauzan Syaikhu Islam, Danar Guruh Pratomo, and Khomsin
}

\begin{abstract}
Coral reefs are one of the major ecosystems in the coastal region with high biodiversity and resource level. As productive ecosystems with high economic and ecological potential, the existence of coral reef ecosystems must be sustainably managed. One of the areas with high diversity of coral reefs is Giligenting Island located in Sumenep regency. This research was conducted by taking primary data in the form of tidal data, bathymetry data and Side Scan Sonar recordings. From the primary data and then processed until produces 3 dimensional model of seabed features that are then interpreted and analyzed to obtain information about healthy or damaged coral reefs, using underwater geo-tagged photos to validate. The 3-dimensional model has a maximum depth of 7.667 meters and 1.403 meters at minimum depth with an area of 100,536.097 $\mathrm{m} 2$. From the interpretation of Side Scan Sonar acoustic images it is found the area of sand feature is $30.79 \%$; the area of mud feature equal to 29.94\%; the healthy coral covering $35.75 \%$ of the survey area, consisting $10.09 \%$ of coral reef barrier reef feature, and $25.66 \%$ of small coral reef feature; and $3.52 \%$ of damaged coral reef feature from total 43,527.110 m2 Side Scan Sonar survey area.
\end{abstract}

\section{Keywords-Coral reefs, 3-Dimension, side scan sonar.}

\section{INTRODUCTION}

Giligenting is one of the islands located in Sumenep regency of Madura. With an area of about $30.32 \mathrm{~km} 2$, the island is located in the southeast of Sumenep regency [1]. Giligenting Island is also known as the island with its beautiful beaches and marine biodiversity is very high, especially the cover of coral reefs are spread almost evenly in the waters of Giligenting Island. However, not many have identified the type and condition of coral reefs in Giligenting, especially the intensity of sea transport intensity and the drilling of oil and gas which is only about $10 \mathrm{~km}$ east of Giligenting Island known as Maleo Block is of course very influential with the condition of coral reefs.

The increasing coral reef damage must be constantly monitored [2]. This is done to determine the steps that must be done to keep the rehabilitate coral cover in Giligenting. One method for monitoring coral reefs is manta-tow, where the observers dive directly and are pulled by a ship with a speed of 0.5 to 1 knot [3]. This method produces video footage to determine the type of coral reef and coral cover is

Fauzan Syaikhu Islam, Danar Guruh Pratomo, and Khomsin are with Department of Geomatics Engineering, Institut Teknologi Sepuluh Nopember, Surabaya, 60111, Indonesia. E-mail: khomsin@geodesy.its.ac.id healthy or damaged, but this method can only present sample data on the survey path.

3 Dimensional Modeling is the most effective data presentation to describe coral damage. Acoustic methods are now widely used to detect the presence of undersea objects. The acoustic system is very effective for exploring the underwater environment [4], therefore hydro-acoustic devices such as Side Scan Sonar (SSS) and Singlebeam Echosounder (SBES) can be used to identify the seabed features [4]. The use of acoustic imaging technology using SSS is one of the most suitable methods for underwater mapping. The use of SSS does not yield depth data, therefore batimetric measurements using SBES are required to produce contours of the seabed features. By integrating SSS data and depth data from SBES, 3 dimensional modeling can be done. Wijonarko in 2016 modeled the seabed features using similar methods with relatively flat ocean floor results without any objects detected by SSS [5].

The purpose of this research is 3D modeling by using seabed elevation from Singlebeam Echosounder which is overlaid with acoustic image of seabed from Side Scan Sonar to determine damaged coral reef at Giligenting Island of Sumenep Regency. The results of this study are expected to be used as reference data for the prevention of destruction by ships and rehabilitation of coral reefs in the area of Giligenting.

\section{METHODOLOGY}

\section{A. Research Location}

The location of research in this final project is in the north of Giligenting Island of Sumenep Regency which is geographically located at $7^{\circ} 10^{\prime} 28^{\prime \prime} \mathrm{S}-113^{\circ} 55^{\prime} 17^{\prime \prime} \mathrm{E}$.

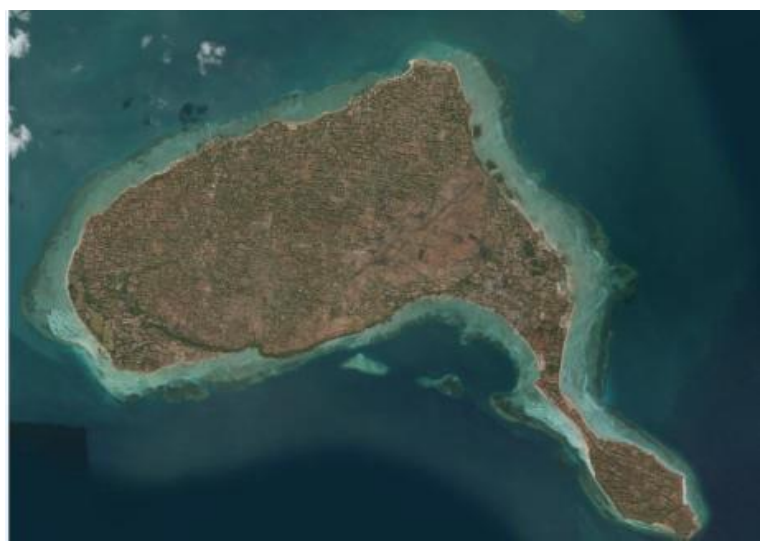

Figure 1. Giligenting Island. 
The Survey is focused at the area with dense coral reefs coverage, which is located along the shoreline with \pm 100 meter distance from shoreline. The Survei area then narrowed down to $1 \mathrm{~km}$ long at the north of the island, located at the west of Sembilan Beach with coordinates $7^{\circ} 10^{\prime} 28^{\prime \prime} \mathrm{S}-113^{\circ}$ 55' 17" E as shown on Fig. 2.

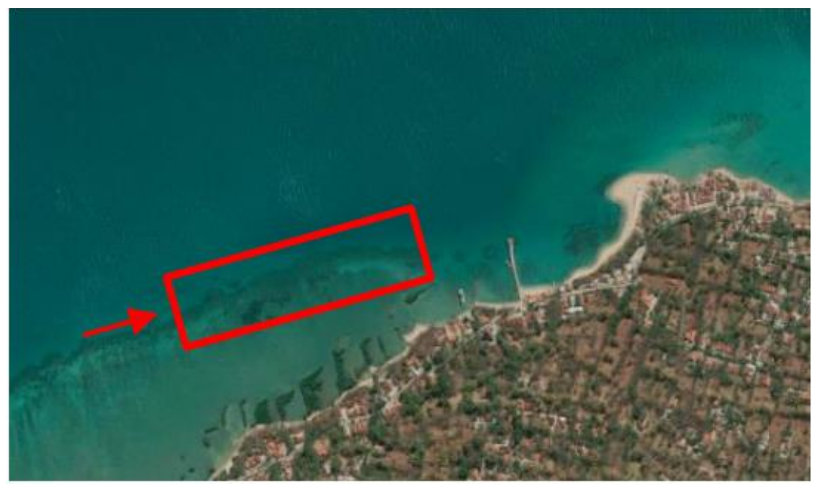

Figure 2. Survey Area.

\section{B. Tools and Data Acquisition}

This research used primary data collected from the field. The data acquisition uses several tools to get the data needed to make 3 Dimensional Model.

1. Tidal Observation. The The observation was held on the 26th to 29th April 2018, located at the Pier of Sembilan Beach at the north of Giligenting Island. The data then combined with tidal model from Badan Informasi Geospasial to get longer tidal observation.

2. Bathymetry survey. The survey was performed using Singlebeam Echosounder HiTarget HD 375 and Garmin Echomap73 sv with Geodetic GPS positioning correction. These two data then combined to get accurate depth of the seafloor.

3. Side Scan Sonar Recording. The acoustic images of the seafloor is acquired using the SideVü feature of the Garmin Echomap 73 sv. The recording is followed by taking underwater photos facing into seafloor with the camera placed beside the tranducers for validation later.

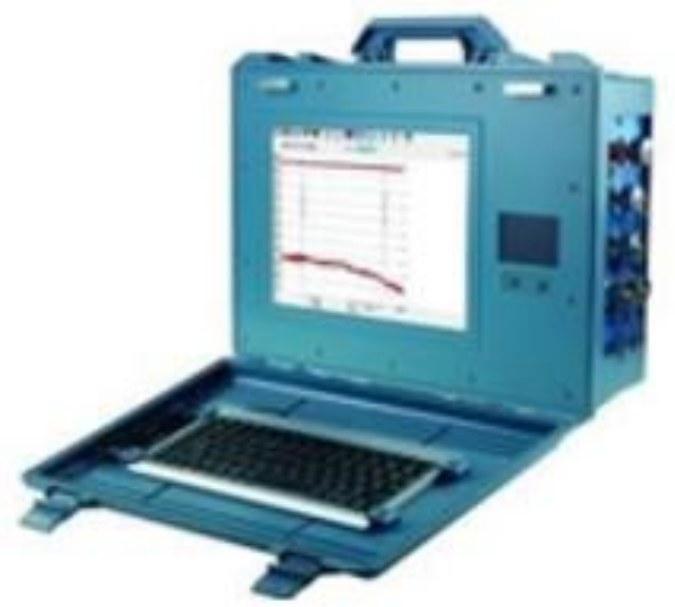

Figure 3. HiTarget HD 375 Singlebeam Echosounder used to record depth.

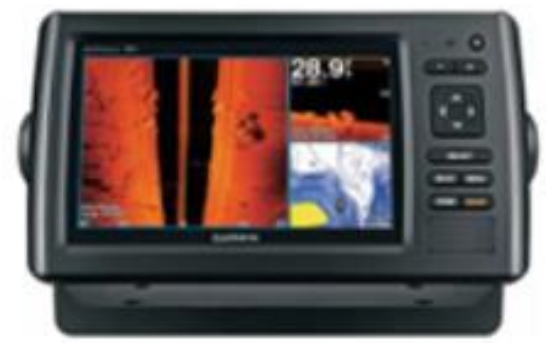

Figure 4. Garmin Echomap 73sv with DownVü for depth and SideVü for acoustic images.

\section{Data Processing}

1) Tidal Processing. The data used combined field observation and tide model for 29 days, with interval observation is 1 hour. Next, calculation of amplitude value and 9 constituent tidal, used to find out value of vertical datum MSL as well as type of tidal with Formzahl formulas bellow:

$$
\mathrm{F}=\frac{\mathrm{AK} 1+\mathrm{AO} 1}{\mathrm{AM} 2+\mathrm{AS} 2}
$$

Wherever $\mathrm{F}$ is number of Formzahl, while AKI, AO1, AM2, and AS2 are amplitude value of each constituen from $\mathrm{K} 1, \mathrm{O} 1, \mathrm{M} 2$, and S2.With this amplitude has a unit of meters. Input of main parameters power current generator is tide data with datum MSL equal to zero, then it is necessary datum shift process. This process will be done by subtracting any tidal observation data against value of MSL on previous calculations.

2) Bathymetry Processing. The Singlebeam Echosounder (SBES) data processing of both devices is corrected with tidal data by interpolating tidal observation time and sounding observation time at each recorded point. The horizontal position of SBES was then corrected by interpolating the sounding observation time and the GPS geodetic recording time of the kinematic method to obtain corrected horizontal coordinate.

3) Acoustic Images Processing. Side Scan Sonar Processing (SSS) is performed using some correction such as Altitude correction, Slant Range Correction and Time Varying Gain.

\section{a. Altitude Correction}

This correction is done to get the first echo return value of the depth of the sea from the SSS tranducers. This correction reduces the noise in the middle of the SSS recordings as shown on Fig. 5a then make it smoother in Fig. $5 b$.

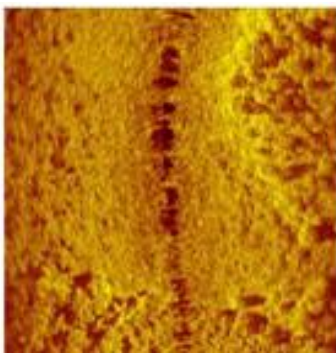

(a)

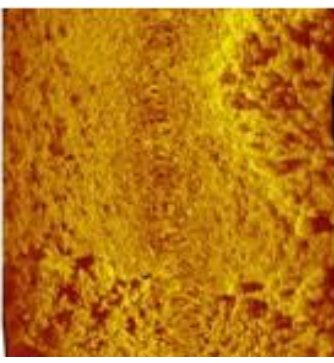

(b)
Figure 5. (a) Side Scan Sonar recordings with noise in the middle, (b) Side Scan Sonar recordings after Altitude corrections. 
b. Slant Range Correction

Slant Range Correction (SRC) is used to calculate the actual distance of a seabed object from the nadir which is then visualized to the acoustic images as shown on Fig. $6 \mathrm{~b}$. SRC also removes the water column seen in the Fig. 6a.

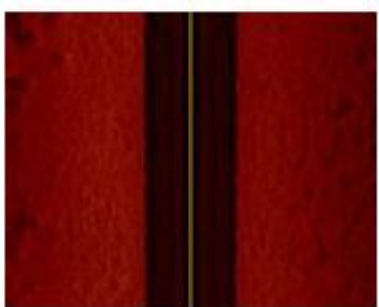

(a)

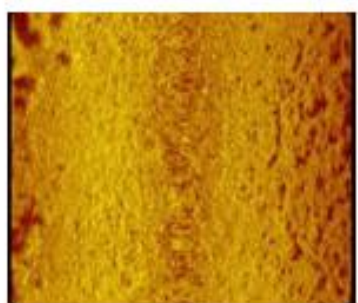

(b)
Figure 6. (a) Side Scan Sonar recordings with water column in the midle, (b) Acoustic Image after slant range correction.

\section{c. Time Varying Gain}

This correction is done to correct the backscatter value weakened at a far distance from nadir, resulting darker images at far sides of both channel shown on fig.7a. Time Varying Gain (TVG) is done by entering the parameter of the gain value that can change with the distance from the nadir (Fig. $7 \mathrm{~b})$.

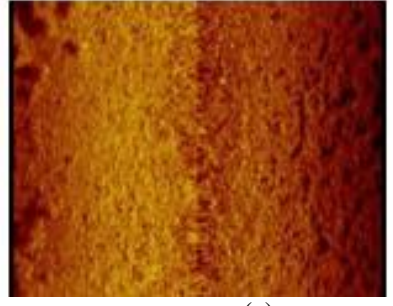

(a)

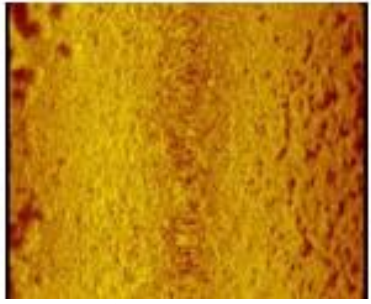

(b)
Figure 7. (a) Acoustic image with darker sides, (b) Corrected image after Time Varying Gain.

4) Side Scan Sonar Images Mosaic. Mosaic is a step taken to combine the SSS acoustic imagery of many recording paths. Mosaic of SSS image is done until the image coverage meets the research area.

5) Three Dimensional Modeling of Seabed Features. 3 Dimensional Modeling of Seabed Features is done by combining 3 dimensional model of Batimetry and Acoustic Image Side Scan Sonar so as to get model representing height and object on the seabed.

\section{RESULT AND DISCUSSION}

\section{A. Tidal Observation}

From tidal observations that have been done with the processing method of least square obtained the value of sea water is shown on Table 1 and the graph is shown on Fig. 8:

TABLE 1.

\begin{tabular}{cc} 
THE VALUE OF REFERENCE DEPTH \\
\hline Reference Depth & Depth $(\mathbf{m})$ \\
\hline MSL & 1.224 \\
LWL & 3.249 \\
HWL & -0.799 \\
\hline
\end{tabular}

July $12^{\text {th }} 2018$, Institut Teknologi Sepuluh Nopember, Surabaya, Indonesia

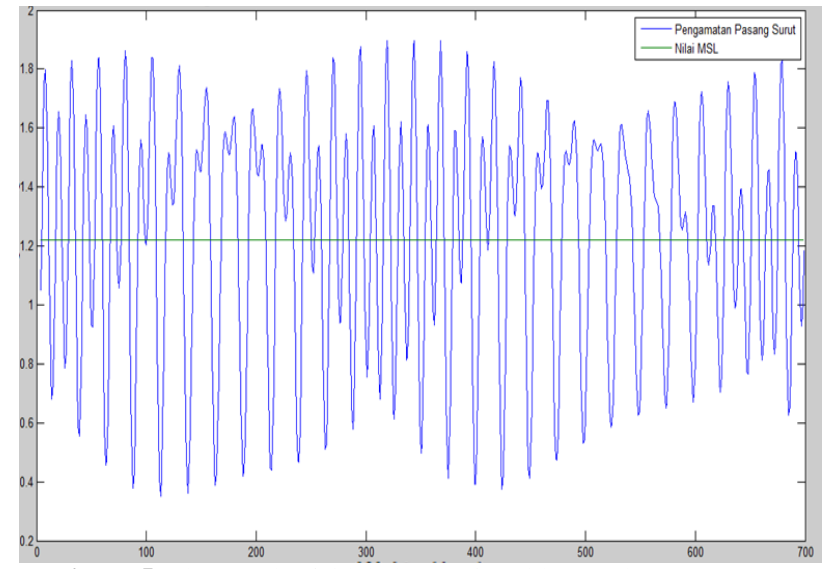

Figure 5. The Graph of tidal observation (blue) and MSL (green)

\section{B. Bathymetry}

The results of bathymetry data processing from HiTarget HD 375 and Garmin Echomap 73sv are as follows:

1. Batimetri HiTarget HD 375 Singlebeam Echosounder. Hi Target line surveys are over \pm 750 meters long and 150 meters wide with 50 meter intervals. From the data processing it is found the maximum depth of 7.635 meters and the minimum at depth 1.407 meter to MSL.

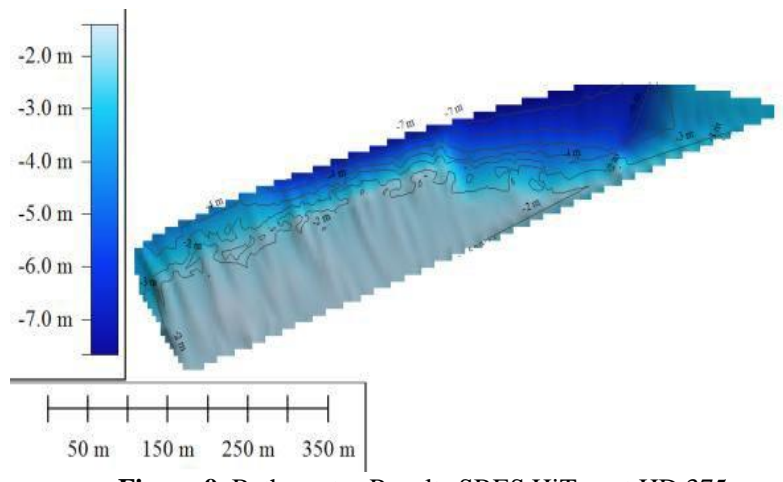

Figure 9. Bathymetry Results SBES HiTarget HD 375

2. Bathymetry Garmin Echomap 73sv. Garmin Echomap has a survey path along \pm 700 meters with width of 50 meters and interval per 10 meters. From the processing, maximum depth of 4.762 meters and the minimum depth of 1.775 meters to MSL is obtained.

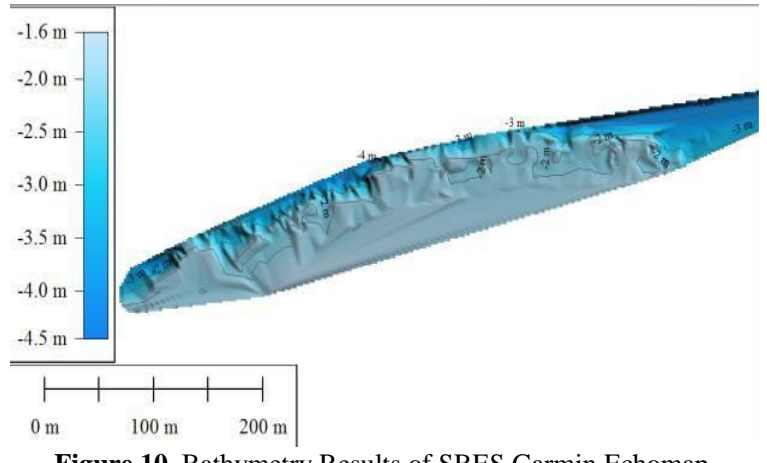

Figure 10. Bathymetry Results of SBES Garmin Echomap. 
The $3^{\text {rd }}$ Geomatics International Conference 2018

July $12^{\text {th }} 2018$, Institut Teknologi Sepuluh Nopember, Surabaya, Indonesia

3. Combined Bathymetry. These two sounding data are combined to obtain a more dense depth value in the SSS survey area with the HiTarget tool as a reference for spike reduction. The total area of SBES survey is $100,536,097 \mathrm{~m}^{2}$.

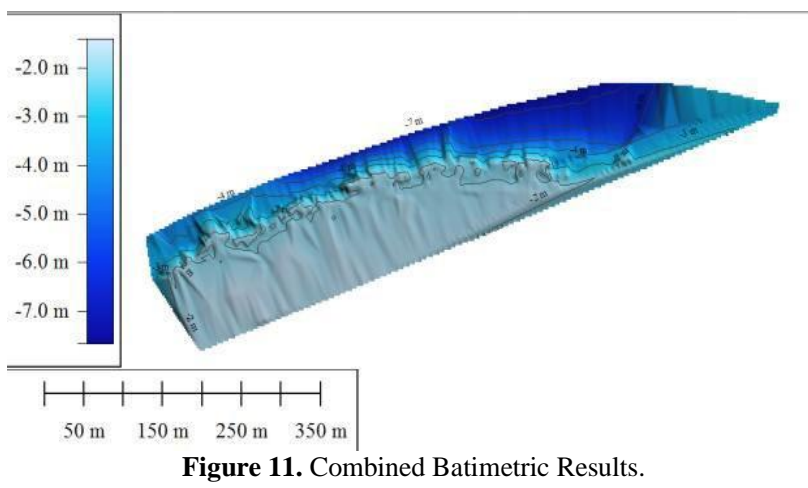

4. 3 Dimensional Model Batimetry. From the depth of bathymetry combined then made 3-dimensional model with Krigging interpolation.

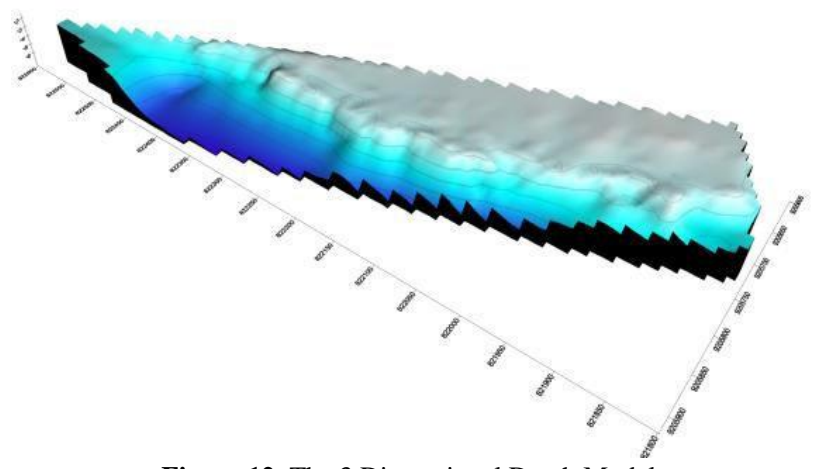

Figure 12. The 3 Dimensional Depth Model.

\section{Side Side Scan Sonar Analysis}

The mosaic of the SSS path is carried out by considering the coverage of the SSS survey area and generating an SSS image of $43,527.110 \mathrm{~m}^{2}$. The SSS image is inside the SBES survey area so it can be overlaid to create a 3 -dimensional model of seabed features.

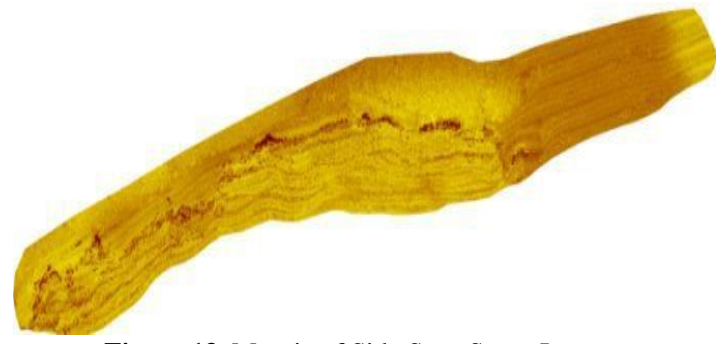

Figure 13. Mosaic of Side Scan Sonar Images.

The result of SSS acoustic image is then interpreted by the seabed feature by observing the interpretation keys of shape, size, hue saturation, pattern and texture [6]. Interpretation results are then validated with underwater photos tied with horizontal coordinates.
1. Sand Feature. Sand can be interpreted with small grain shape, very small size $(<0.1$ meter $)$, bright hue saturation, smooth pattern and texture without shadow.

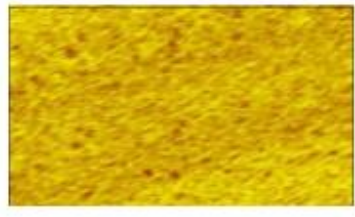

(a)

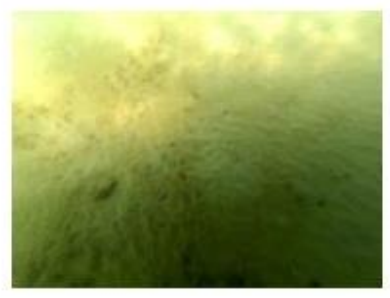

(b)
Figure 14. Sand feature in acoustic images, (b) Underwater photo for validation of sand feature.

2. The Mud Feature. Mud can be interpreted with small grain shape, very small size $(<0.1$ meter $)$, dark hue saturation, smooth pattern and texture without shadow.

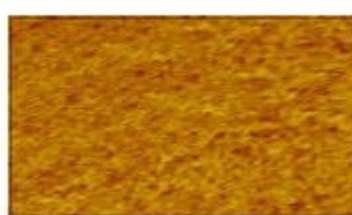

(a)

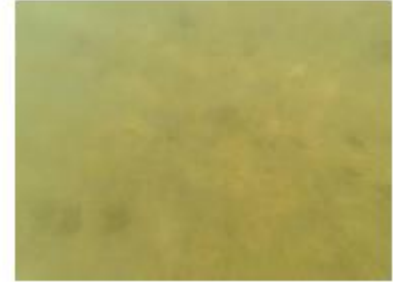

(b)
Figure 15. (a) Mud feature in acoustic images, (b) Underwater photo for validation of mud feature.

3. Barrier Reefs Corals Feature. The barrier reefs corals can be interpreted as coral boulders, large size ( $>2$ meters), bright hue saturation with shadow, pattern and texture of large coral bunches.

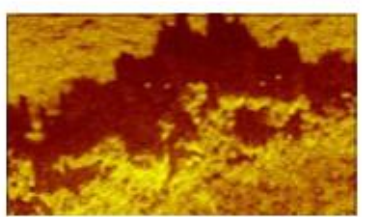

(a)

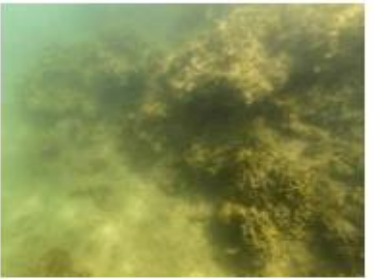

(b)
Figure 16. (a) Barrier Reefs feature in acoustic images, (b) Underwater photo for validation of Barrier reefs feature.

4. Fringing Reefs Corals Feature. Small coral reefs can be interpreted in terms of coral, small $(<1$ meter), bright hue saturation with shadow, small texture and texture patterns.

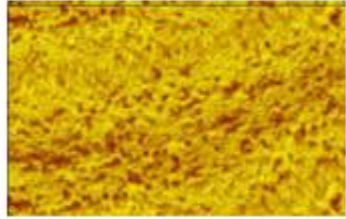

(a)

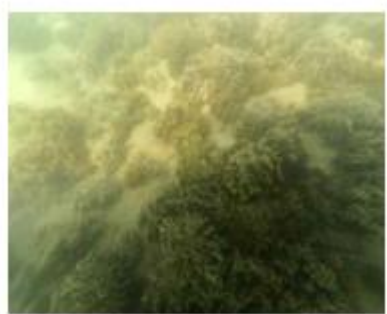

(b)
Figure 17. (a) Fringing Reefs feature in acoustic images, (b) Underwater photo for validation of Fringing reefs feature 
5. Damaged Coral Reefs Features. Features of damaged or dead coral reefs can be interpreted in fine form with little corals, small size $(<1$ meter), bright hue saturation with shadow, patterns and textures of a few coral dominated by sand.

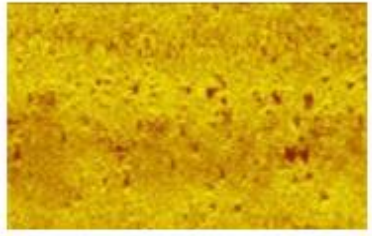

(a)

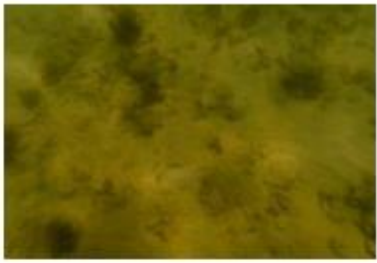

(b)
Figure 18. (a) Damaged Reefs feature in acoustic images, (b) Underwater photo for validation of Damaged reefs feature.

From the interpretation of acoustic image obtained the following results:

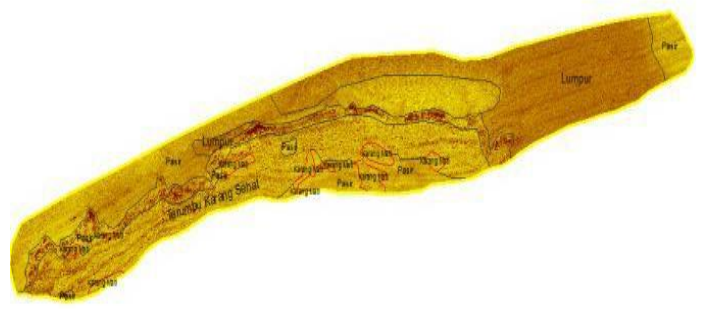

Figure 19. Interpretation of Side Scan Sonar Acoustic Image.

With details of area as follows:

TABLE 2.

OVERVIEW OF SEABED FEATURE FROM INTERPRETATION

\begin{tabular}{clc}
\hline \hline No & Seabed Features & Width $\left(\mathbf{m}^{2}\right)$ \\
\hline 1 & Sand & 13401.997 \\
2 & Mud & 13032.017 \\
3 & Barrier Reefs Coral & 4391.885 \\
4 & Fringing Reefs Coral & 11169.056 \\
5 & Damages Coral Reefs & 1532.154 \\
\hline \hline
\end{tabular}

\section{Three Dimensinal Seabed Feature.}

The 3 dimensional model shows the area of the interpreted seabed features have depth information. Then from the 3D model could be analyzed the factors of the damaged coral
July $12^{\text {th }} 2018$, Institut Teknologi Sepuluh Nopember, Surabaya, Indonesia

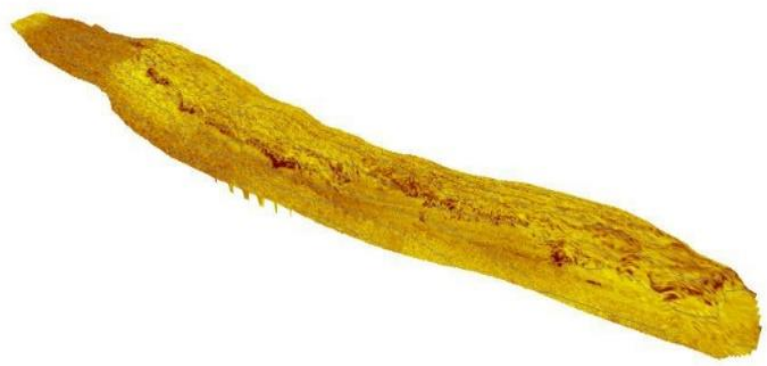

Figure 20. 3D Seabed Feature shows the depth of each feature class. The corals scattered at depth 1.3-3 meter.

\section{CONCLUSION}

Based on the results of processing and data analysis has been done. The 3-dimensional model has a maximum depth of 7.667 meters and 1.403 meters at minimum depth with an area of $100,536.097 \mathrm{~m}^{2}$. From the interpretation of Side Scan Sonar acoustic images it is found the area of sand feature is $30.79 \%$; the area of mud feature equal to $29.94 \%$; the healthy coral covering $35.75 \%$ of the survey area, consisting $10.09 \%$ of coral reef barrier reef feature, and $25.66 \%$ of small coral reef feature; and $3.52 \%$ of damaged coral reef feature from total 43,527.110 $\mathrm{m}^{2}$ Side Scan Sonar survey area.

\section{REFERENCES}

[1] [BPS] Badan Pusat Statistika, "Kecamatan Giligenting Dalam Angka," Sumenep, 2018.

[2] Coral Alliance, "Coral Reefs and Sustainable Marine Recreation," 2006.

[3] Y. Fahmi, "Pemetaan Kondisi Terumbu Karang Di Desa Sumberkencono Kabupaten Banyuwangi," Surabaya, 2014.

[4] P. Blondel, The Hand Book of Side Scan Sonar. United Kingdom: Praxis Publishing Ltd, 2009.

[5] W. Wijonarko, "Kajian Pemodelan Dasar Laut Menggunakan Side Scan Sonar dan Singlebeam Echosounder," J. Geod. Undip, vol. 5, no. 2, 2016.

[6] Klein Associates Inc, Side Scan Sonar Record Interpretation. New Hampshire: Klein Associates, Inc, 1985. 